\title{
WARISAN METODE PENDIDIKAN ISLAM UNTUK GENERASI MILLENNIAL
}

\section{Zaini Miftah}

zmiftah0106@gmail.com

IAI Sunan Giri Bojonegoro

\begin{abstract}
One of the inheritances of Islamic teachings which is very fundamental in achieving educational outcomes is the learning method. Therefore, this learning method will be very effective and active in encouraging students to be able to develop their potential to be better, ranging from intelligence, personality, character and skills that are useful for themselves and society. Islamic religious education and humans have a very fast dynamism, where Islamic religious education will survive for all ages, so that whenever and anyone who learns it will be able to receive the same and complete understanding of the sources of Islamic religious education, while humans when attached as social beings then there will be a challenge for him to be able to accept the changing times.

This writing method is a literature review with a descriptive and exploratory approach which can be concluded that the method of Islamic religious education is an educational method with regular and systematic work and thinking of all the factors that exist to achieve the objectives of Islamic religious education, to deliver material Islamic education effectively and efficiently requires dynamic methods and approaches, including the Hiwar Qur'ani and Nabawi Method, the Stories of the Qur'ani and Nabawi, Amtsal Qur'ani and Nabawi, Uswah Hasanah, Tadrib and Tajribah, Ibrah and Mau 'Idzah, and Targhib and Tarhib
\end{abstract}

Keywords: Methode, Islamic Education, Millennial Generation 


\section{A. Pendahuluan}

Perkembangan dan kemajuan sebuah bangsa ditunjukkan oleh beberapa faktor, salah satunya adalah pendidikan. Sebuah bangsa akan dinilai baik jika politik pendidikan bangsa tersebut dalam keadaan yang baik. Pendidikan diibaratkan sebagai faktor penentu bagi terciptanya sumber daya manusia yang kompeten dan kredibel dalam perannya membangun bangsa. Dalam dinamika kehidupan sosial manusia dituntut untuk terus mengaktualisasikan diri bagaimana ia mampu bersaing dan berkompetisi dalam kehidupan global. Oleh karena itu lahirnya term yang merujuk kepada pendidikan bahwa suatu proses pembelajaran yang dilakukan tidak ada kata henti dan stagnan sehingga pemikiran yang memunculkan istilah pendidikan sepanjang hayat adalah shohih dan tidak terbantahkan.

Terkait proses pendidikan dalam skala luas, menurut Marvin Harris bahwa pendidikan akan membentuk sebuah budaya. Kebudayaan merupakan implikasi dari aspek kehidupan manusia termasuk pikiran dan tingkah laku dalam masyarakat yang diperoleh dalam belajar hasilnya cara belajar dan tujuan belajar seperti apa yang mendukung kemajuan, kedamaian dan keadilan. Inilah yang harus menjadi tugas institusi dan pelaku pendidikan agar memiliki agenda dan tugas untuk merumuskan serta mengarahkan pribadi tiap manusia sesuai dengan tujuan dan cita-citanya. ${ }^{1}$

Kemudian terkait usaha untuk mengarahkan dan merumuskan para peserta didik kearah yang lebih baik, penulis melihat bahwa metode pendidikan sangat menjadi perhatian bagi pendidikan di Indonesia, karena dengan beban mata pelajaran yang sangat banyak dan kedisiplinan para peserta didik yang lemah dalam hal belajar, maka harus dicari solusi agar para peserta didik bisa menyerap dan mengaplikasikan hasil belajar dengan cepat. Karena kerugian yang sangat besar bagi pendidikan apabila para peserta didik bingung dan tidak bisa

1 M. Haitami Salim dan Syamsul Kurniawan, Studi Pendidikan Islam, (Jogjakarta : Arruz-Media cet 1 2012,) hal 5, lihat Rifa'I Al-Ghazali, Pendidikan Berbasis Ajaran Agama Dan Kebudayaan Masyarakat Indonesia Dalam Menghadapi Arus Global, E-Jurnal.UPI.edu 2018,hlm 3 
mengaplikasikan hasil belajarnya kepada kehidupannya sehari-hari sehingga akan menimbulkan split orientasi dan gagal dalam kehidupannya kelak.

Dalam pendidikan Islam, metode mempunyai kedudukan yang sangat penting dalam upaya mencapai tujuan, karena ia menjadi sarana yang akan memberi makna bagi materi pelajaran yang tersusun dalam kurikulum pendidikan, sehingga dapat dipahami atau diserap oleh peserta didik menjadi pengertian yang fungsional terhadap tingkah lakunya, bahkan dalam sebuah maqolah bahasa Arab yang sering terdengar At-thariqah ahammu mina-l-maaddah yang mempunyai arti bahwa metode lebih penting dari pada materi. Maqolah ini bukan tanpa maksud dalam pelajaran agama Islam, hal ini tentu menjadi acuan bahwa metode merupakan sebuah keniscayaan bagi seorang guru untuk menyampaikan bagaimana makna dan maksud dari pembelajaran, karena akan sia-sia apabila materinya bagus namun metode yang dipakai membosankan dan bertele-tele, tentunya metode-metode yang digunakankan sesuai dengan apa yang dicontohkan nabi Muhammad saw dan para Sahabat. ${ }^{2}$

Mengutip perkataan M. Arifin terkait pentingnya metode, ia sebagai salah satu komponen operasional ilmu pendidikan, metode harus mengandung potensi yang bersifat mengarahkan materi pelajaran kepada tujuan pendidikan yang hendak dicapai melalui proses tahap demi tahap, baik dalam kelembagaan formal maupun yang non formal ataupun yang informal. ${ }^{3}$

Kemudian berbicara pendidikan kita tidak akan terlepas dengan kaitannya antara manusia dan pendidikan, manusia sebagai objek pendidikan adalah mahluk dinamis yang akan selalu menerima dan mengalami perubahan, sehingga pendidikan pun harus terus mengikuti dinamika perubahan manusia pada zaman tersebut. Terdapat hal menarik dimana pada era modern dan keterbukaan ini

2 Muzayyin Arifin, Filsafat Pendidikan Islam, (Jakarta: PT Bumi Aksara, 2009), hlm 67, lihat M.Kholil Asy'ari, Metode Pendidikan Islam, Jurnal Qothruna Vol 1 No.1 2014, hlm 194

3 M.Arifin, Ilmu Pendidikan Islam Suatu Tinjauan Teoritis dan Praktis Berdasarkan Pendekatan Interdisipliner, (Jakarta : Bumi Aksara, edisi I, 1991),hlm. 65, lihat Nurjannah Riannie, pendekatan dan Metode Pendidikan Islam ( sebuah perbandingan dalam konsep teori pendidikan Islam dan barat ), Jurnal Management of Education, Volume 1 Issue 2, 2015, hlm 105 
muncul suatu istilah bagi mereka manusia yang lahir berdasarkan fase tahunnya, ide ini muncul setelah perang dunia ke-2 yang mana teori ini disebut teori generasi yang dipercaya akan mempengaruhi seseorang pada masa yang akan datang.

Di masa modern ini, kita sering mendengar istilah millennial generation atau generasi Y yang juga akrab disebut generation me atau echo boomers. ${ }^{4}$ Secara harfiah memang tidak ada demografi khusus dalam menentukan kelompok generasi yang satu ini. Mereka yang termasuk dalam angkatan digital oleh para pakar menggolongkannya berdasarkan tahun awal dan akhir. Penggolongan generasi Y terbentuk bagi mereka yang lahir pada 1980 - 1990, atau pada awal 2000, dan seterusnya.

Berdasarkan infografis pusat data media Republika, menyebutkan ada sekitar 80 juta millennials lahir pada 1976 - 2001. Dimana para Millennials rata rata mengalihkan perhatiannya pada $\mathrm{PC}$, smartphone, tablet, dan televisi 27 kali setiap jamnya. Angka ini meningkat dari 17 kali per jam di generasi sebelumnya. Pada urusan bekerja, millennial lebih tertarik memiliki pekerjaan yang bermakna ketimbang sekadar bayaran yang besar. Sedangkan dalam urusan konsumsi hiburan, millennial menghabiskan 18 jam perhari untuk menikmati layanan tontonan on demand, bermain gim, atau sekadar menonton televisi konvensional.

Secara umum generasi millenial memiliki karakter sangat akrab dengan media dan internet. Mereka juga terbuka terhadap ide dan gagasan orang lain. Namun di sisi lain mereka rawan memiliki potensi karakter negatif seperti kurang

\footnotetext{
$4 \quad$ Yang pertama generasi baby boomer ( 1946-1964), yaitu generasi yang lahir setelah perang dunia ke 2, memiliki banyak anak, mudah bergaul dan mudah menerima dan mempunyai banyak pengalaman hidup; yang kedua adalah generasi X ( 1965-1980), merupakan generasi yang lahir dengan bertipe kerja keras, mandiri, mampu beradaptasi dan menerima perubahan; ketiga generasi Y atau disebut juga millineal ( 1981-1994 ), yaitu generasi yang sudah menggunakan sesuatu dengan teknologi, instan, senang dengan game online, rasa penasaran yang tinggi, rasa ingin tahu dan gandrung akan media social; keempat generasi Z ( 1995- 2010 ), yaitu generasi yang sejak kecil sudah terbiasa dengan gadget, bisa mengerjakan sesuatu dengan bersamaan seperti bermain game dan media sosial, cenderung ingin instan dan cepat; dan yang kelima generasi alpa ( 2011-2025 ) yaitu generasi yang terdidik, mapan, suka akan kekayaan dan cenderung suka berbelanja. Lihat http/dosenperbanas/ Natali Yustisa, Teori Generasi, diakses 25 Juli 2019
} 
peka terhadap lingkungan sosial, pola hidup bebas, cenderung bersikap individualistik, kurang realistis, dan kurang bijak dalam menggunakan media.

Melihat fenomena yang menarik diatas, penulis mencoba merumuskan bagaimana metode pembelajaran yang tepat dan efektif bagi masing-masing individu berdasarkan generasinya, seperti halnya generasi millennial yang potensi untuk selalu dan setiap waktu update akan informasi karena begitu intensnya bergelut dengan teknologi ${ }^{5}$ karena keanekaragaman generasi manusia ini adalah fitrah dan hal yang patut disyukuri, kemudian dalam konteks pendidikan keanekaragaman tersebut mempunyai metode atau tipe-tipe belajar yang berbeda. Fakta tersebut menjadi acuan para pelaku pendidikan untuk menerapkan metode pembelajaran yang cocok bagi peserta didik.

Dalam pendidikan Islam ada sebuah istilah bahwa علمو أو لادكم فإنهم مخلوقون (ajarkanlah anakmu dengan kadar atau metode sesuai dengan zamannya), ungkapan ini mengindikasikan bahwa setiap individu harus diajarkan menggunakan metode yang tepat agar maksud dan makna pembelajaran tersampaikan dengan baik dan benar, sejalan dengan itu bahwa Islam mengajarkan nilai-nilai dimana pendidikan harus berlangsung dan dikembangkan secara konsisten untuk mencapai tujuannya. ${ }^{6}$ Berdasarkan uraian di atas, maka penulis melakukan penelitian dalam rangka penulisan yang menyangkut tentang warisan metode pendidikan Islam untuk generasi millennial.

Penulis menggunakan istilah "warisan" karena metode pendidikan yang diterapkan merupakan teori dan praktek yang telah lama diajarkan dan dilaksanakan serta merupakan hazanah ilmiah tinggalan sejarah Islam yang akan diwariskan pada generasi millennial untuk diterapkan.

4 Abraham Zakky Zulhazmi dan Dewi Ayu Sri Hastuti, "Da'wa, Muslim Millenials and Social Media," LENTERA: Jurnal Ilmu Dakwah Dan Komunikasi 2, no. 2 (28 Desember 2018), hal, 5 A\&madi, Islam Sebagai Paradigma Ilmu Pendidikan, Yogyakarta: Aditya Media, 1992, 


\section{B. Pembahasan dan Hasil Penelitian}

\section{Pengertian Metode}

Metode adalah suatu jalan yang dilalui untuk mencapai sebuah tujuan, metode berasal dari kata yunani yaitu meta dan hodos. Meta berarti melalui dan hodos berarti jalan atau cara; kemudian metode berkaitan erat dengan metodologi yang mana mempunyai arti ilmu tentang jalan atau cara yang dilalui untuk mencapai tujuan. ${ }^{7}$ Sedangkan dalam Kamus Besar Bahasa Indonesia sebagaimana yang dikutip oleh Erwati Aziz, metode mengandung arti cara yang teratur dan terpikir baik-baik untuk mencapai maksud (dalam ilmu pengetahuan dan sebagainya); cara kerja yang bersistem untuk memudahkan pelaksanaan suatu kegiatan guna mencapai tujuan yang ditentukan. ${ }^{8}$

Sedangkan para ahli mendefinisikan metode sebagai berikut :

a. Hasan Langgulung mendefinisikan bahwa metode mengajar adalah jalan yang dipergunakan guru dalam mengadakan hubungan dengan peserta didik pada saat berlangsungnya proses pembelajaran. Dengan demikian metode mengajar merupaka alat untuk menciptakan proses pembelajaran. ${ }^{9}$

b. Muhammad Atiyah Al-Abrasy mengatakan bahwa metode merupakan jalan yang digunakan pendidik untuk memberikan pengertian kepada peserta didik tentang segala materi dalam proses pembelajaran. ${ }^{10}$

Berdasarkan beberapa definisi diatas dapat disimpulkan bahwa metode adalah seperangkat jalan atau cara atau tehnik yang dimiliki oleh pendidik dalam upaya menyampaikan dan memberikan pengajaran agar tercapainya tujuan pembelajaran.

6 Abuddin Nata, Filsafat Pendidikan Islam, (Jakarta: Gaya Media Pratama, 2006), hlm. 144

7 Erwati Aziz. Prinsip-prinsip Pendidikan Islam . ( Surakarta : PT Tiga Serangkai,2013) hal.79, lihat Mumtazul Fikri, Konsep Pendidikan Islam" Pendekatan Metode Pengajaran, Jurnal Ilmiah Islam Futura Volume XI, No 1 agustus 2017, hlm 118

8 Hasan Langgulung, Beberapa Pemikiran tentang Pendidikan Islam, (Bandung: PT al-Ma'arif, 2006), hlm. 183

9 Tim Depag RI, Islam untuk Disiplin Ilmu Pendidikan, (Jakarta: P3AI-PTU, 2000), hlm.157, lihat Ahmad Syukri Harahap, Metode Pendidikan Islam Dalam Persfektif Filsafat pendidikan Islam, Jurnal Hikmah, Volume 15, No 1 Juni 2018, hlm 14 
Perumusan pengertian metode biasanya disandingkan dengan teknik, yang mana keduanya saling berhubungan. Metode pendidikan adalah prosedur umum dalam penyampaian materi untuk mencapai tujuan pendidikan didasarkan atas asumsi tertentu tentang hakikat sebagai subsistem pendidikan. Sedangkan teknik pendidikan adalah langkah-langkah konkret pada waktu seorang pendidik melaksanakan pengajaran di kelas. ${ }^{11}$

Apabila metode dipandang sebagai alat untuk mencapai tujuan pendidikan, maka metode mempunyai fungsi ganda, yaitu yang bersifat lipolipragmatis dan monopragmatis. ${ }^{12}$ Polipragmatis bilamana metode menggunakan kegunaan yang serba ganda (multipurpose), misalnya suatu metode tertentu pada suatu situasikondisi tertentu dapat digunakan untuk merusak, dan pada kondisi yang lain bisa digunakan membangun dan memperbaiki. Kegunaannya dapat bergantung pada si pemakai atau pada corak, bentuk, dan kemampuan dari metode sebagai alat. Sebaliknya, monopragmatis bilamana metode mengandung implikasi bersifat konsisten, sistematis, dan kebermaknaan menurut kondisi sasarannya, mengingat sasaran metode adalah manusia, sehingga pendidik dituntut untuk berhati-hati dalam penerapannya.

Metode mempunyai jalan atau tugas sebaik mungkin bagi pelaksanaan operasional dari sebuah ilmu pendidikan, pelaksanaannya berada dalam ruang lingkup proses kependidikan yang berada dalam sistem dan struktur kelembagaan yang diciptakan untuk mencapai tujuan pendidikan. Bila kita pahami metode sebagai subsistem ilmu pendidikan maka pendekatan-pendekatan yang dipakai harus sesuai dengan sumber disiplin ilmu tersebut. ${ }^{13}$

Dalam penerapannya metode pendidikan harus memperhatikan permasalahan individu dan sosial para peserta didik dan pendidik tentunya, dalam metode pendidikan Islam khususnya ada dasar-dasar umum yang harus diterapkan yaitu :

\footnotetext{
10 Depag.RI, Metodologi Pendidikan Agama Islam (Jakarta: Dirjen Binbaga Islam, 2001), hal, 90 1 M.Arifin, Ilmu Pendidikan Islam Suatu Tinjauan Teoritis dan Praktis Berdasarkan Pendekatan Interdisipliner, (Jakarta : Bumi Aksara, edisi I, 1991),hlm 98

12 Ibid, hal 102
} 
a. Dasar religious, yang menitik beratkan bahwa manusia adalah mahluk religious dan agama adalah dasar sebagai metode pengajaran bagi pendidik.

b. Dasar filosofis, yang memandang manusia adalah mahluk rasional, sehingga segala sesuatu yang menyangkut perkembangannya didasarkan pada sejauh mana kemampuan berpikirnya dapat dikembangkan sampai titik maksimal perkembangannya.

c. Dasar sosiokultur, yang tertumpu bahwa manusia adalah mahluk yang bermasyarakat dan berkebudayaan dan disebut juga homosapiens, dengan demikian pengaruh lingkungan dan kebudayaannya sangat besar bagi proses pendidikan individualnya.

d. Dasar scientific, yang berpandagan bahwa manusia memliki kemampuan mencipta (kognitif) dan berkemauan (konatif) dan merasa (afektif) sehingga pendidikan harus dapat mengembangkan kemampuan analitis dan reflektif dalam berpikir. ${ }^{14}$

Dalam konteks pendidikan Islam metode yang tepat guna apabila mengandung nilai-nilai intrinsik dan ekstrinsik sejalan dengan materi pelajaran dan secara fugsional dapat dipakai untuk merealisasikan nilai ideal yang terkandung dalam tujuan pendidikan. Ada tiga aspek nilai yang terkadung dalam tujuan pendidikan Islam yang hendak direalisasikan melalui metode pendidikan: 1) membentuk hamba Allah yang hanya mengabdi kepada-Nya semata, 2) edukatif yang mengacu pada petunjuk Al-Quran dan Hadis, 3) berkaitan dengan motivasi dan disiplin sesuai apa yang dicontohkan Nabi Muhammad SAW dan para sahabatnya. $^{15}$

13 Mahfudz Shalahuddin, Metodologi Pendidikan Agama, (Surabaya: Bina Ilmu, 2000) hal 45, lihat juga HM,Arifin ,Ilmu Pendidikan Islam hal 65

14 M. Haitami Salim dan Syamsul Kurniawan, Studi Pendidikan Islam, (Jogjakarta : Arruz-Media cet 1 2012,) hal,165 


\section{Pengertian Pendidikan Islam}

Dalam konteks Islam istilah pendidikan mengacu kepada makna dan asal kata yang membentuk kata pendidikan itu sendiri dalam hubungannya dengan ajaran Islam, maka pada konteks ini perlu juga dikaji sehingga bisa digunakan dalam arti definitif. Ada tiga istilah yang digunakan dalam pendidikan Islam yaitu at-Tarbiyah, al-Ta'lim, al-Ta'dib, istilah ini mempunyai makna masing-masing diantaranya adalah :

At-Tarbiyah dalam Al-Quran memang tidak ditemukakan secara khusus namun istilah tersebut dinisbatkan kepada $a r-R a b b$, Rabbayani, Rabbani,dan Ribbiyun. Kemudian apabila at-Tarbiyah diidentikkan dengan $a r-R a b b$ para ahli memberikan pengertian beragam, al-Qurthubi memberikan makna $a r-R a b b$ dengan pemilik, tuan, yang maha memperbaiki, yang maha mengatur, yang maha menunaikan. Sedangkan Fahrurozi berpendapat $a r-R a b b$ seakar dengan atTarbiyah yang mempunyai makna al-Tanmiyah, pertumbuhan dan perkembangan, menurutnya kata Rabbayani tidak hanya mencakup pengajaran yang bersifat ucapan, tetapi juga meliputi pengajaran yang bersifat sikap dan tingkah laku. ${ }^{16}$

Jika merujuk pada kamus bahasa Arab istilah at-Tarbiyah merujuk pada Raba-Yarbu artinya bertambah, Rabiya -Yarba artinya tumbuh dan RabbaYarubbu artinya memperbaiki dan mengurusi kepentingan. ${ }^{17}$ Menurut Imam Baidowi; ar-Rabb itu bermakna tarbiyah, yang makna lengkapnya adalah menyampaikan sesuatu hingga mencapai kesempurnaan. Kemudian kata itu dijadikan sifat Allah SWT sebagai mubalaghah (penekanan). ${ }^{18}$ Sementara Naquib al-atas menjelaskan bahwa tarbiyah mengandung pengertian mendidik, memelihara, menjaga dan membina semua ciptaannya. Dan kosakata Rabb dijadikan salah satu rujukan dalam menyusun konsep pendidikan Islam.

15 M. Haitami Salim dan Syamsul Kurniawan, Studi Pendidikan Islam, (Jogjakarta : Arruz-Media cet 1 2012,) hal, 30

16 Ramayulis, Ilmu Pendidikan Islam, (Jakarta: Kalam Mulia, 2002), hlm. 2

17 Abdurrahman an-Nahlawi, Prinsip-Prinsip dan Metoda Pendidikan Islam Dalam Keluarga, di Sekolah, dan di Masyarakat, alih bahasa, Herry Noer Ali, (Jakarta: Gema Insani Press, 1996), hlm 31 
Selain konsep tarbiyah digunakan pula konsep ta'lim untuk pendidikan. Islam secara etimologi berkonotasi pembelajaran yaitu semacam proses transfer ilmu pengetahuan. Menurut Abdul Fattah Jalal, konsep-konsep pendidikan yang terkandung di dalamnya adalah sebagai berikut; Pertama, ta'lim adalah proses pembelajaran terus menerus sejak manusia lahir melalui pengembangan fungsifungsi pendengaran, penglihatan dan hati. Pengertian ini digali dari firman Allah SWT yang terjemahannya sebagai berikut: "Dan Allah mengeluarkan kamu dari perut ibumu dalam keadaan tidak mengetahui sesuatu pun dan Dia memberi kamu pendengaran, penglihatan, dan hati agar kamu bersyukur." (Q.S. al-Nahl/16:78).

Pengembangan fungsi-fungsi tersebut merupakan tanggung jawab orang tua ketika anak masih kecil. Setelah dewasa, hendaknya orang belajar secara mandiri sampai ia tidak mampu lagi meneruskan belajarnya, baik karena meninggal atau karena usia tua renta. Kedua, proses ta'lim tidak berhenti pada pencapaian pengetahuan dalam domain kognisi semata, tetapi terus menjangkau wilayah psikomotor dan afeksi. Pengetahuan yang hanya sampai pada batas-batas wilayah kognisi tidak akan mendorong seorang untuk mengamalkannya, dan pengetahuan semacam itu biasanya diperoleh atas dasar prasangka atau taqlid. Padahal al-Qur'an sangat mengecam orang yang hanya memiliki pengetahuan semacam ini. ${ }^{19}$

Muhammad Rasyid Ridha memberikan definisi ta'lim sebagai proses transmisi berbagai ilmu pengetahuan pada jiwa individu, tanpa adanya batasan dan ketentuan tertentu. Penjelasan itu berpijak pada firman Allah SWT (QS. AlBaqarah: 31) tentang bagaimana Tuhan mengajarkan kepada Nabi Adam As, yang mana transmisi itu dilakukankan secara bertahap. ${ }^{20}$ At-talim merupakan bagian kecil dari at-tarbiyah al-aqliyah yang bertujuan memperoleh pengetahuan dan keahlian berpikir yang sifatnya mangacu pada domain kognitif, hal ini dapat dipahami dari pemakaian kata 'allama dalam surah al-baqarah ayat 31 yang

18 Bukhari Umar, Ilmu Pendidikan Islam, ( Jakarta, Bumi Aksara, 2010 ) hal 23

19 Ibid, hal 24, lihat ahmad syah, Term Tarbiyah, Talim, dan Tadib Dalam Pendidikan Islam"Tinjauan dari aspek Semantik, Al-Fikra Jurnal Ilmiah KeIslaman, Vol 7, No 1 Juni 2018, hlm 145 
dikaitkan kata 'aradha yang mengimplikasikan bahwa proses pengajaran Adam pada akhirnya diakhiri pada tahap evaluasi.

Istilah ketiga yang digunakan untuk menunjukkan kepada pendidikan adalah Adab. Arti dasar istilah ini adalah "undangan kepada suatu perjamuan". Ibn Mandzur juga menyebutkan ungkapan "addabahu fataaddaba" berarti allamahu (mendidiknya). Gagasan ke suatu perjamuan mengisyaratkan bahwa tuan rumah adalah orang yang mulia dan adanya banyak orang yang hadir, dan bahwasanya yang hadir adalah orang-orang yang menurut perkiraan tuan rumah pantas mendapatkan kehormatan untuk diundang, dan oleh karena itu, mereka adalah orang-orang bermutu dan berpendidikan tinggi yang diharapkan bisa bertingkah laku sesuai dengan keadaan, baik dalam berbicara, bertindak maupun etika. ${ }^{21}$

Muhammad Nadi Al-Badri mengemukakan sebagaimana dikutip oleh Ramayulis, bahwa pada zaman klasik orang yang mengenal kata ta'dib untuk menunjukkan kegiatan pendidikan, pengertian ini terus terpakai sepanjang kejayaaan Islam. Sehingga ilmu pengetahuan yang dihasilkan oleh akal manusia pada masa itu disebut Adab, baik yang berhubungan langsung dengan Islam seperti fiqih, tafsir, tauhid, ilmu bahasa arab dan sebagainya. Maupun yang tidak berhubungan langsung seperti fisika, astronomi, kedokteran, falasafah dan lainnya, semua buku yang ditulis dinamai kutub al-adab, dan dikenal adab al-kabir dan $a d a b$ as-shagir yang ditulis oleh Ibnu al-Muqaffa ( W.760 M) dan seorang pendidik pada masa itu disebut muaddib. ${ }^{22}$

Adapun pengertian pendidikan Islam dapat dijelaskan sebagai berikut; Prof Omar Muhammad Asy-Syaibani mendefinisikan pendidikan Islam adalah proses mengubah tingkah laku individu pada kehidupan pribadi, masyarakat dan alam sekitar, dengan cara pengajaran sebagai suatu aktivitas asasi. ${ }^{23}$ Pengertian ini

20 Muhammad Naquib al-attas, The Concept of Education in Islam: A Frame Work for an Islamic Phylosophy of Education, Terj. Haidar Bagir (Bandung: Mizan, 1996) hal 56-57

21 Ramayulis, Metodologi Pengajaran Agama Islam, ( Jakarta, Kalam Mulia 1990), hal 6

22 Omar Muhammad asy-syaibani, Falsafah Pendidikan Islam, Terj, Hasan Langgulung ( Jakarta, Bulan Bintang 1979 ) Hal,399 
menekankan pada konotasi pendidikan etika selain itu menekankan pada aspek produktivitas dan kreativitas dalam peran kehidupan dimasyarakat dan alam.

Dr M Fadhil Jamali memberikan pengertian pendidikan Islam sebagai upaya mengembangkan, mendorong, serta mengajak manusia lebih maju dengan berlandaskan nilai-nilai yang agung dan mulia sehingga terbentuk pribadi yang sempurna. ${ }^{24}$ Menurut Abdurrahman an-Nahlawi, pendidikan Islam adalah penataan individual dan sosial yang dapat menyebabkan seseorang tunduk, taat pada Islam dan menerapkannya secara sempurna di dalam kehidupan individu dan masyarakat. Pendidikan Islam merupakan kebutuhan mutlak untuk dapat melaksanakan Islam sebagaimana yang dikehendaki oleh Allah. Berdasarkan makna ini, maka pendidikan Islam mempersiapkan diri manusia guna melaksanakan amanat yang dipikulkan kepadanya. Ini berarti, sumber-sumber Islam dan pendidikan Islam itu sama, yakni yang terpenting, al-Qur'an dan Sunnah Rasul. $^{25}$

Dari beberapa pengertian diatas dikatakan bahwa pendidikan Islam adalah proses tranformasi dan internalisasi ilmu pengetahuan dan nilai-nilai pada peserta didik melalui penumbuhan dan pengembangan potensi fitrahnya guna mencapai keselarasan dan kesempurnaan hidup dalam segala aspeknya. Walaupun istilah pendidikan Islam tersebut dapat dipahami secara berbeda, namun pada hakikatnya merupakan satu kesatuan dan mewujud secara operasional dalam satu sistem yang utuh. Konsep dan teori kependidikan Islam sebagaimana yang dibangun atau dipahami dan dikembangkan dari al-Qur'an dan As-sunnah, mendapatkan legitimasi dan perwujudan secara operasional dalam proses pembudayaan dan pewarisan serta pengembangan ajaran agama, budaya dan peradaban Islam dari generasi ke generasi, yang berlangsung sepanjang sejarah umat Islam. ${ }^{26}$

23 M Fadhil jamali, Filsafat Pendidikan dalam Al-Quran. Terj. Judial fasalani, (Surabaya, Bina Ilmu 1986 ) hal 3

24 Abdurrahman an-Nahlawi, Prinsip-Prinsip dan Metoda Pendidikan Islam dalam Keluarga, di Sekolah dan di Masyarakat, (Bandung: CV.Diponegoro, 1996), hlm. 41.

25 Muhaimin, Paradigma Pendidikan Islam Upaya Mengefektifkan Pendidikan Agama Islam di Sekolah, (Bandung: PT Remaja Rosdakarya, 2002), hlm. 30. 


\section{Sumber Pendidikan Islam}

Sumber pendidikan Islam yang dimaksudkan disini adalah semua acuan atau rujukan yang mengandung ilmu pengetahuan yang didalamnya terdapat nilainilai yang akan diinternalisasikan dalam pendidikan Islam, menurut Said Ismail Ali yang dikutip oleh Hasan Langgulung bahwa sumber pendidikan Islam terdiri atas enam macam, yaitu Al-Quran, Sunnah, kata-kata Sahabat, kemaslahatan Umat, tradisi atau adat, dan Ijitihad. ${ }^{27}$

Kemudian Muhammad Alim mengatakan bahwa sebagian Ulama berpendapat sumber pendidikan Islam yang paling utama ada dua, yaitu Al-Qur'an dan As-Sunnah. Kemudian penalaran atau akal pikiran adalah sebagai alat bantu untuk memahami Al-Qur'an dan As-Sunnah. ${ }^{28}$

\section{Generasi Millennial}

Terdapat banyak fenomena menarik dewasa ini, salah satunya yang sedang ramai dibicarakan oleh publik adalah generasi millennial. Saat ini Indonesia sudah memasuki era millenial, jaringan internet ada di mana-mana. Diperlukan pendekatan khusus untuk mendidik mahasiswa era millennial.

Maraknya budaya global dan gaya hidup pop culture, fenomena ini dianggap sebagai dampak dari arus globalisasi yang sudah tidak dapat dibendung lagi. Globalisasi yang sering dimaknai sebagai proses mendunianya sistem sosial, ekonomi, politik, dan budaya sehingga dunia terkesan tanpa batas (borderless world). Dengan adanya satelit, internet, dan telepon jarak yang jauh terasa dekat. Perkembangan teknologi dan informasi telah menghapus batas antarnegara, antarbangsa, dan antarkelas. Salah satu proses penting dari globalisasi adalah

\footnotetext{
Hasan Langgulung, Asas-asas Pendidikan Islam, ( Jakarta, Pustaka Alhusna, 1988 ) hal 35 Muhammad Alim. Pendidikan Agama Islam: Upaya Pembentukan Pemikiran dan Kepribadian Muslim. Bandung: Remaja Rosdakarya. 2006 Hlm. 169
} 
melahirkan generasi gadget, istilah yang sering digunakan untuk menandakan lahirnya generasi millennial. ${ }^{29}$

Milenial (juga dikenal sebagai Generasi Y) adalah kelompok demografi setelah Generasi X (Gen-X). Tidak ada batas waktu yang pasti untuk awal dan akhir dari kelompok ini. Para ahli dan peneliti biasanya menggunakan awal 1980an sebagai awal kelahiran kelompok ini dan pertengahan tahun 1990-an hingga awal 2000-an sebagai akhir kelahiran. Milenial pada umumnya adalah anak-anak dari generasi Baby Boomers dan Gen-X yang tua. Milenial kadang-kadang disebut sebagai "Echo Boomers" karena adanya 'booming' (peningkatan besar) tingkat kelahiran di tahun 1980-an dan 1990-an. Untungnya di abad ke 20 tren menuju keluarga yang lebih kecil di negara-negara maju terus berkembang, sehingga dampak relatif dari "baby boom echo" umumnya tidak sebesar dari masa ledakan populasi pasca Perang Dunia II. ${ }^{30}$

Kemudian membicarakan generasi millennial ada beberapa isu utama yang menjadi bagian penting bagi strategi bagaimana generasi ini akan menjadi hal yang positif bagi kemajuan agama dan bangsa kelak yaitu:

a. Pandangan tentang agama

Pandangan ini sangat penting bagi generasi millennial karena walau bagaimanapun Indonesia khususnya adalah Negara yang bermayoritaskan agama Islam, walaupun dasar Negara memakai pancasila dan UUD 1945 namun tetap dasar agama dan falsafah kehidupan harus berdasarkan keagamaan, karena pada generasi ini begitu kencangnya arus globaliasasi dan teknologi sehingga kadang norma agama sering kali dilupakan bahkan mereka lebih mementingkan gadget dari pada ajaran agama.

b. Nilai- nilai sosial

Bagaimana seorang manusia harus memaknai arti sebuah keluarga dan lingkungan sekitar, karena hubungan antara manusia, baik keluarga, maupun teman

28 Yanuar Surya putra, Teori Perbedaan Generasi, Jurnal Stiema, 2017, hal 6

29 Panjaitan, Pengaruh Sosial Media Terhadap Produktivitas Kerja Generasi Millennial, Jurnal Admintrasi Bisnis,2017, hal 7 
akan menjadi tempat perlindugan yang baik, berbagai masalah yang akan timbul bagi generasi ini yaitu kurangnya sosialisasi. Mereka lebih suka berinteraksi dengan menggunakan gedgetnya sehingga akan terjadi pergeseran nilai-nilai sosial.

c. Pendidikan

Isu yang paling penting di kalangan generasi ini adalah pendidikan, isu ini yang akan mengarahkan bagaimana ia akan menuju masa depan, akan tetapi permasalahan yang muncul sangat riskan pada generasi ini, mereka cenderung malas karena faktor informasi yang mereka dapatkan begitu mudah dengan mengunakan gadget, mereka hanya menempatkan sekolah hanya sebagai penggugur kewajiban yang dilegalkan dengan ijazah, sehingga banyak bagi mereka pendidikan bukan lagi prioritas. ${ }^{31}$

\section{Metode Pendidikan Islam Untuk generasi Millennial}

Setelah kita memahami makna metode dan pendidikan Islam serta karakteristik generasi millennial, penulis bisa mengambarkan betapa pentingnya metode bagi transformasi ilmu kepada peserta didik, karena metode merupakan cara atau tehnik bagaimana peserta didik mampu menyerap pembelajaran yang diberikan, kemudian tentunya metode yang digunakan berdasarkan prinsip dasar pendidikan Islam. Sangat menarik ketika penulis memahami bahwa tingkah laku manusia sebagai mahluk sosial yang berbeda secara sturktur pikiran dan kondisi kultur sosiologis yang ada dan berpengaruh bagi manusia tersebut untuk bagaimana belajar dan menerima pelajaran, oleh karena itu penulis mencoba mencari cara yang tepat bagaimana supaya pembelajaran akan tersampaikan secara efektif dan efesien.

Metode mengajar yang umum dikenal dalam dunia pendidikan hingga sekarang adalah metode ceramah, metode diskusi, metode eksperimen, metode demontarsi, metode sosiodrama, metode drill, metode kelompok dan metode proyek serta lainnya, semua metode ini bisa dipakai berdasarkan kepentingan

30 Debora Cornelia Risambessy, Generasi Millennial (Makalah Ilmu Budaya Dasar,Jurusan Psikologi Universitas Gundarma,2017) hal 5 
masing-masing, sesuai bahan yang akan diberikan harus juga berdasarkan nilainilai efektif.

Metode pendidikan Islam sebagaimana kita tahu pengertiannya yaitu caracara yang digunakan dalam mengembangkan potensi anak didik untuk mencapai tujuan pendidikan Islam. Dalam metode pendidikan Islam ada pendekatan khsusus bagi tercapainya tujuan pendidikan Islam itu sendiri:

1. Pendekatan Tilawah yaitu meliputi membaca ayat-ayat Allah secara kauniyah dan kitabiyah yang mana makna terdalam dari pendekatan tilawah adalah tadabbur, tafakkur, tadzakkur, sedangkan aplikasinya adalah kegiatan-kegiatan ilmiah, pengakajian serta lainnya.

2. Pendekatan Tazkiyah (pensucian) yaitu mensucikan diri dengan amal ma'ruf dan nahi munkar, pendekatan ini memelihara kebersihan hati, akhlak dan pikiran. Aplikasinya adalah control sosial, memelihara Islam dan lainnya.

3. Pendekatan Ta'lim al-kitab dan Ta'lim al-hikmah yaitu pendekatan yang menjelaskan tentang berpegang teguh kepada al-Quran dan as-Sunnah serta perenungan yang mendalam tentang hikmah ayat-ayat Allah apliaksinya adalah studi banding antar lembaga, pembelajaran al-quran dengan berkelompok diskusi dan lainnya.

4. Pendekatan mukjizat kebesaran Allah swt yaitu pendekatan yang membawa peserta didik kepada pengalaman belajar yang tidak pernah mereka temui, sehingga rasa keingin tahuan peserta didik tinggi dan akan meimbulkan sifat kritis dalam hal belajar.

5. Pendekatan Islah (perbaikan) yaitu pendekatan memperbaiki diri menjadi yang lebih baik, mempunyai cita-cita yang tinggi, untuk masa depan yang lebih baik sehingga dimasa mendatang para peserta didik mampu menjadi bagian masyrakat yang berguna. $^{32}$

31 Jalaludin Rahmat, Islam Alternatif, ( Bandung.Mizan,1991 ) hal,117-119, lihat juga Abd Mannan, Tujuan,Materi, dan Metode Pendidikan Islam Persfektif Ibn Khaldun, Jurnal Islamuna Volume 3 No. 1 Juni 2016, hlm 149- 151 
Kemudian menurut Prof Omar Syaibani menyatakan bahwa seorang pendidik perlu memperhatikan tujuh prinsip pokok metode pendidikan Islam yaitu:

1. Mengetahui motivasi, kebutuhan dan minat peserta didik.

2. Mengetahui tujuan pendidikan yang sudah ditetapkan.

3. Mengetahui tahap kematangan, perkembangan, serta perubahan peserta didik.

4. Mengetahui perbedaan individu peserta didik.

5. Memperhatikan pemahaman, pengalaman,dan kebebasan berpikir.

6. Menjadikan proses pendidikan sebagai pengalaman mengembirakan bagi peserta didik.

7. Menegakkan uswatun hasanah. ${ }^{33}$

Beberapa metode pendidikan Islam, mengutip dari Abdurahman AnNahlawi yang dapat digunakan adalah :

1. Pendidikan dengan Hiwar Qurani dan Nabawi yaitu hiwar artinya dialog percakapan silih berganti anatar dua pihak mengenai suatu topic yang mengarah pada satu tujuan, hiwar Qurani adalah dialog Allah swt dengan hambanya, sedangkan hiwar Nabawi dialog antara nabi dan sahabatnya.

2. Pendidikan dengan kisah Qurani dan Nabawi yaitu kisah yang mengandung fungsi edukatif karena kisah dalam Al-quran dan Nabawi mempunyai keistimewaan yang membuat efek psikologis yang sempurna.

3. Pendidikan dengan Amtsal (perumpamaan) Qur'ani yaitu menyamakan sesuatu dengan yang lainnya kebaikan dengan keburukan dan orang musyrik yang menjadikan pelindung selain 
Allah swt dengan laba-laba membuat rumah ( al-ankabut ayat 41 ), tujuan pedagogis yang dapat ditarik perumpamaannya adalah: a) mendekatkan makna pada pemahaman, b) merangsang kesan pesan yang berkaitan dengan makna yang tersirat, c) mendidik akal supaya berpikir sehat benar dan mengunakan kias yang logis, d) mengerakkan perasaan yang mendorong untuk melakukan amal baik dan menjauhi kemunkaran.

4. Pendidikan dengan Uswah Hasanah (teladan) yaitu dilakukakn oleh pendidik dengan menampilkan prilaku yang baik didepan peserta didik, berperilaku akhlaqul karimah dengan disengaja dan tidak disegaja dalam rangka memberikan contoh yang baik bagi peserta didik.

5. Pendidikan dengan Tadrib (pelatihan) dan Tajribah (pengalaman) yaitu salah satu metode yang dilakukan Rasulallah dalam mendidik para sahabatnya dengan cara latihan yang mana rasul memperintahkan mempraktikkan cara-cara melakukan ibadah.

6. Pendidikan dengan Ibrah dan Mauidzah Hasanah yaitu pendidik mengajak para peserta didik mengetahui inti dari sari perkara dan pelajaran yang disaksikan sehingga kesimpulannya menyentuh hati, sedangkan Mauidzah adalah pemberian nasihat dan peringatan agar kebaikan dengan cara menyentuh qolbunya.

7. Pendidikan dengan Targhib dan Tarhib yaitu janji serta hal yang menyenangkan bagi peserta didik, untuk melakukan hal yang bermanfaat sehingga akan mendapatkan nikmat yang kekal diakhirat. $^{34}$

33 Abdurrahman an-Nahlawi, Prinsip-Prinsip dan Metode Pendidikan Islam dalam Keluarga, di Sekolah dan di Masyarakat, (Bandung: CV.Diponegoro, 1996), hlm 283-284, lihat Fadriati, Prinsip-Prinsip Metode Pendidikan Islam Dalam Al-Quran, Jurnal Ta'dib, Volume 15, No.1 Juni 2012, hlm 85-90 
Setelah penulis memaparkan beberapa metode pendidikan Islam dan prinsip pokok metode pendidikan Islam maka penulis melihat bahwa metode pendidikan Islam yang tepat digunakan bagi generasi millennial adalah:

Pertama; metode pendidikan Hiwar Qurani dan Nabawi, metode ini cocok karena generasi millennial cenderung mempunyai rasa ingin tahu yang tinggi dikarenakan factor teknologi yang mudah diakses mengakibatkan generasi ini mampu berdialog dengan satu arah untuk mencapai tujuan pembelajaran;

Kedua metode pendidikan Amtsal, yaitu perumpamaan menyamakan sesuatu dengan sesuatu yang mana tujuan pedagogis dalam metode ini akan membawa generasi millennial merangsang kesan dan pesan yang terkait dengan makna yang tersirat serta mendidik akal supaya berpikir logis dan sehat, dan ini sesuai dengan sifat generasi millennial yang biasa berpikir rasional;

Ketiga metode pendidikan Uswah Hasanah, yaitu teladan, generasi millenal perlu adanya rule model bagi dirinya sehingga pendidikan dengan teladan ini akan mampu membawa kesan baik dan efektif bagi mereka;

Keempat metode pendidikan Tadrib (latihan) dan Tajribah (pengamalan), metode ini sangat penting karena sifat millinneal bukan hanya ingin menyaksikan saja namun mereka mempunyai sifat ingin mencoba sehingga metode akan sangat efektif bagi mereka;

Kelima pendidikan dengan Ibrah dan Mauidzah, metode ini adalah metode yang sangat riskan sebetulnya karena terkesan menakuti dan hanya memberi nasihat semata, namun poin yang diambil dari metode ini adalah bagaimana generasi millennial cendurung kosong hatinya dan secara psikologis mereka gampang tersentuh, oleh karena itu metode ini harus disampaikan dengan baik dan sempurna. 


\section{Kesimpulan}

Dari uraian diatas, dapat disimpulkan bahwa salah satu warisan hazanah ilmiah dalam pendidikan Islam adalah metode pendidikan. Metode pendidikan akan mendapatkan perhatian yang sangat besar dalam mengantar generasi millennial menuju generasi yang berperadaban. AlQuran dan al- Hadits merupakan sumber utama ajaran Islam berisi prinsip-prinsip dan petunjuk-petunjuk yang dapat dipahami dan diinterpretasikan menjadi konsep-konsep tentang metode. Selanjutnya tidak ada metode yang tidak bisa digunakan dalam pembelajaran, namun lebih tepatnya apabila kita bisa melihat dan merumuskan apa metode yang efektif bagi peserta didik, berkembangnya zaman dan berubahnya tingkah laku para peserta didik akan menjadi bagian dinamika pendidikan itu sendiri. Setidaknya terdapat lima metode pendidikan yang bisa diterapkan untuk generasi millennial, yaitu: Hiwar Qurani dan Nabawi, Amtsal, Uswah Hasanah, Tadrib dan Tajribah, serta Ibrah dan Mauidzah.

Oleh karena itu seyogyanya kita sebagai praktisi pendidikan harus bisa menempatkan pendidikan pada dasar dan tujuan yang benar, yaitu dengan mengarahkan peserta didik kita untuk selalu belajar sepanjang hayatnya. Generasi millenial adalah generasi yang banyak tantangan, kaum muda yang diharapkan mampu meneruskan langkah masa depan bangsa dan agama, kita pupuk kita rawat dan arahkan kepada hakikat pendidikan Islam dengan tuntunan al-Quran dan al-Hadits. 


\section{DAFTAR PUSTAKA}

Ahmadi, Islam Sebagai Paradigma Ilmu Pendidikan, Yogyakarta: Aditya Media, 1992

Al-Ghazali Rifa'I, Pendidikan Berbasis Ajaran Agama Dan Kebudayaan Masyarakat Indonesia Dalam Menghadapi Arus Global, EJurnal.UPI.edu 2018

Alim Muhammad Pendidikan Agama Islam: Upaya Pembentukan Pemikiran dan Kepribadian Muslim. Bandung: Remaja Rosdakarya. 2006

Arifin Muzayyin, Filsafat Pendidikan Islam, Jakarta: PT Bumi Aksara, 2009 An-Nahlawi Abdurrahman, Prinsip-Prinsip dan Metoda Pendidikan Islam Dalam Keluarga, di Sekolah, dan di Masyarakat, alih bahasa, Herry Noer Ali, Jakarta: Gema Insani Press, 1996

Arifin, HM . Ilmu Pendidikan Islam Suatu Tinjauan Teoritis dan Praktis Berdasarkan Pendekatan Interdisipliner, Jakarta : Bumi Aksara, edisi I, 1991

Asy'ari M.Kholil, Metode Pendidikan Islam, Jurnal Qothruna Vol 1 No.1 2014

Aziz Erwati. Prinsip-prinsip Pendidikan Islam, Surakarta: PT Tiga Serangkai, 2013

Bahri Syaiful Djamarah, Guru dan Anak Didik dalam Interaksi Edukatif, Jakarta: Rineka cipta, 2000

Cornelia Debora Risambessy, Generasi Millennial (Makalah Ilmu Budaya Dasar, Jurusan Psikologi Universitas Gunadarma, 2017

Daud Ali. Muhammad Pendidikan Agama Islam. Jakarta: Raja Grafindo Persada, 1998

D. Marimba, Ahmad, Pengantar Filsafat Pendidikan, Bandung: PT alMa'arif, 1998 
Fikri, Mumtajul Konsep Pendidikan Islam” Pendekatan Metode Pengajaran,

Jurnal Ilmiah Islam Futura Volume XI, No 1 agustus 2017

Fadriati, Prinsip-Prinsip Metode Pendidikan Islam Dalam Al-Quran, Jurnal Ta'dib, Volume 15, No.1 Juni 2012

Jamali, Fadhil ,M. Filsafat Pendidikan dalam Al-Quran. Terj. Judial Fasalani, Surabaya: Bina Ilmu, 1986

Langgulung, Hasan Beberapa Pemikiran tentang Pendidikan Islam, Bandung: PT. al-Ma'arif, 2006

Nata Abudin, Filsafat Pendidikan Islam, Jakarta: Gaya Media Pratama, 2006 Naquib Muhammad al-attas, The Concept of Education in Islam: A Frame Work for an Islamic Phylosophy of Education, Terj. Haidar Bagir, Bandung: Mizan, 1996

Muhaimin, Paradigma Pendidikan Islam Upaya Mengefektifkan Pendidikan Agama Islam di Sekolah, Bandung: PT Remaja Rosdakarya, 2002

Mannan Abd, Tujuan, Materi, dan Metode Pendidikan Islam Persfektif Ibn Khaldun, Jurnal Islamuna Volume 3 No. 1 Juni 2016

Omar Muhammad asy-Syaibani, Falsafah Pendidikan Islam, Terj, Hasan Langgulung, Jakarta: Bulan Bintang, 1979

Panjaitan, Pengaruh Sosial Media Terhadap Produktivitas Kerja Generasi Millennial, Jurnal Admintrasi Bisnis, 2017

Ramayulis, Metodologi Pengajaran Agama Islam, Jakarta: Kalam Mulia, 1990

Rahmat, Jalaludin Islam Alternatif, Bandung: Mizan, 1991

Riannie Nurjannah, Pendekatan dan Metode Pendidikan Islam (Sebuah perbandingan dalam konsep teori pendidikan Islam dan barat), Jurnal Management of Education, Volume 1 Issue 2, 2015

Salim Haitami dan Syamsul Kurniawan, Studi Pendidikan Islam, Jogjakarta: Arruz-Media cet 1, 2012 
Syukri Ahmad Harahap, Metode Pendidikan Islam Dalam Persfektif Filsafat Pendidikan Islam, Jurnal Hikmah, Volume 15, No 1 Juni 2018

Syah Ahmad, Term Tarbiyah, Talim, dan Tadib Dalam Pendidikan Islam”Tinjauan dari aspek Semantik, Al-Fikra Jurnal Ilmiah KeIslaman, Vol 7, No 1 Juni 2018

Surya Yanuar putra, Teori Perbedaan Generasi, Jurnal Stiema, 2017

Shalahuddin Nahfudz, Metodologi Pendidikan Agama, Surabaya: Bina Ilmu, 2000

Tafsir Ahmad, Filsafat Pendidikan Islami Integrasi Jasmani,Ruhani dan Kalbu Memanusiakan manusia, (Bandung: Remaja Rosdakarya, Cet.I, 2006

Umar Bukhari, Ilmu Pendidikan Islam, Jakarta: Bumi Aksara, 2010

Wahana, HD, Pengaruh Nilai-Nilai Budaya Generasi Millennial dan Budaya Sekolah Terhadap Ketahanan Individu, Jurnal UGM 2016

Tim Depag RI, Islam untuk Disiplin Ilmu Pendidikan, Jakarta: P3AI-PTU, 2000

Depag.RI, Metodologi Pendidikan Agama Islam Jakarta: Dirjen Binbaga Islam, 2001

Undang-Undang RI No. 20 tahun 2003, Jakarta: BP.Cipta Jaya, 2003

Zulhazmi, Abraham Zakky, dan Dewi Ayu Sri Hastuti. "Da'wah, Muslim Millenials and Social Media." LENTERA: Jurnal Ilmu Dakwah Dan Komunikasi 2, no. 2 (28 Desember 2018) 